\title{
Building a Constituency for Racial Integration: Chicago's Magnet Schools and the Prehistory of School Choice
}

\section{Nicholas Kryczka}

Chicago's magnet schools were one of the nation's earliest experiments in choicedriven school desegregation, originating among civil rights advocates and academic education experts in the 1960s and appearing at specific sites in Chicago's urban landscape during the 1970s. The specific concerns that motivated the creation of magnet schools during the civil rights era-desegregating schools and arresting white flight - were decisively wedded to notions of parental choice, academic selectivity, and urban revitalization. While magnet schools enacted innovative curricula in self-consciously multicultural spaces, their scarcity, combined with their function as a spur to middle-class urbanism, ratified new regimes of inequality in urban education. This article frames magnet schools' engineered success as a necessary prehistory for the rise of educational choice-and-accountability reforms later in the twentieth century.

In April 1982, Chicago Public Schools superintendent Ruth Love published an open letter to parents announcing that the upcoming school year would mark a new chapter in the history of public education. Although prompted by a school desegregation consent decree, Love explained, the demographics of a "majority-minority" system meant that most schools would not find their racial realities altered. What was new was the "exciting array of programs" from which Love encouraged parents to find the "School of Your Choice." Chicago's program leaned on an ascendant reform concept, the magnet school,

Nicholas Kryczka is a PhD candidate in History at the University of Chicago and a former Chicago public schoolteacher. Thanks are due to many Chicago-based archivists for their assistance, the participants in the University of Chicago's US History Workshop, and the Newberry Library's Urban History Dissertation Working Group. Thanks also to the Black Metropolis Research Consortium and the Illinois State Historical Society for fellowship and scholarship support.

${ }^{1}$ Ruth Love, "September' 82 : The School of Your Choice," special supplement, Chicago Sun Times, April 23, 1982, 1. 
already thriving in over a hundred school districts nationwide. ${ }^{2}$ But the magnet concept's success was the product of a peculiar history, rooted in the problems faced by Benjamin Willis, who had held Love's job some two decades earlier. It was at that moment, when Willis faced an aggressive civil rights challenge to the neighborhood-school concept, and when Chicagoans scrambled to organize a response to white flight, that the magnet concept was born. ${ }^{3}$ This article offers a history of the origins of the magnet school, arguing that the introduction of parental choice into school administration during the civil rights era generated new definitions of success for integrated education, marked particular urban spaces with the promise of that success, and in doing so, ratified new regimes of inequality in urban education.

Black Chicago's confrontation with Willis has earned an iconic status in histories of urban schools and the northern civil rights movement. ${ }^{4}$ In the classic exposition, Willis's intransigent posture and prolonged tenure at the helm of a major school system during the urban north's fiercest civil rights challenge was a tragedy, both for the longer arc of racialized politics in Chicago and for the inequitable distribution of educational resources that persisted. ${ }^{5}$ Other accounts highlight Mayor Richard J. Daley's political clout, as his successful deflection of federal intervention blocked an emerging civil rights legal strategy attacking de facto segregation regimes. ${ }^{6}$ As for the program of school desegregation that James Redmond, Willis's successor, began to implement in 1967, historians have judged it a "pie-in-the sky,"

${ }^{2}$ Rolf K. Blank, et al., Survey of Magnet Schools. Analyzing a Model for Quality Integrated Education (Washington, DC: US Department of Education, Office of Planning, Budget and Evaluation, 1983), 10.

${ }^{3}$ For a complication of "white flight" in Chicago, see Amanda I. Seligman, Block by Block: Neighborhoods and Public Policy on Chicago's West Side (Chicago: University of Chicago Press, 2005), 212-16.

${ }^{4}$ Mary J. Herrick, The Chicago Schools: A Social and Political History (Beverly Hills, CA: Sage Publications, 1970); Paul E. Peterson, School Politics, Chicago Style (Chicago: University of Chicago Press, 1976); Alan B. Anderson and George W. Pickering, Confronting the Color Line: The Broken Promise of the Civil Rights Movement in Chicago (Athens: University of Georgia Press, 1986); James R. Ralph, Northern Protest: Martin Luther King Jr., Chicago, and the Civil Rights Movement (Cambridge, MA: Harvard University Press, 1993); and Dionne Danns, Desegregating Chicago's Schools: Policy Implementation, Politics, and Protest, 1965-1985 (New York: Palgrave Macmillan, 2014).

5ohn L. Rury, "Race, Space, and the Politics of Chicago's Public Schools: Benjamin Willis and the Tragedy of Urban Education," History of Education Quarterly 39, no. 2 (Summer 1999), 117-42.

${ }^{6}$ Matthew F. Delmont, Why Busing Failed: Race, Media, and the National Resistance to School Desegregation (Berkeley: University of California Press, 2016), 67-68. 
"bureaucratic daydream," of "limited" proportions. ${ }^{7}$ Whether viewed against the best hopes of the movement that preceded Redmond's plan, the tepid deployment of federal power that occasioned it, or the abject failure of citywide desegregation that followed it, these assessments are undoubtedly correct.

The Redmond Plan, however, did not come from nowhere and its "voluntary" approach to school improvement and integration went on to live a long and influential life. In its immediate context, the plan distilled the lessons of a decade's worth of sociological research, civil rights agitation, and neighborhood politics among the urban middle class. The policies that made it into Chicago's 1967 desegregation plan-expanded school attendance boundaries, racial quotas, and parental choice - constituted the triumph of an anti-neighborhood school view, concentrating prevailing assumptions about black uplift, white flight, and urban revitalization built during the Willis era. These assumptions found expression in the one reform of the Redmond Plan that had staying power- the magnet school. When the city's first magnet schools opened in 1968, consultants, educators, and parents revived the integrationism of the early 1960s, but under the scaled-down conditions of a controlled experiment. In these new educational spaces, Chicagoans improvised an antiauthoritarian interracial order, which some saw as the fulfillment of the social movement activism of the sixties. During the mid-1970s, however, magnet schools' social prestige, driven by the inducement of parents to choose and be chosen, sharpened the selective edge of these specialized programs. By the time Superintendent Love announced that the 1980s heralded a wave of new options, the practice of choice had imparted significant lessons about what "worked" in urban education and how schools could square the tensions between post-civil rights era values of liberal multiculturalism and competitive meritocracy.

This article proceeds in three parts. First, I revisit the high point of the Chicago school crisis to reveal how conceptions of parental choice, racial stabilization, and academic selectivity structured the strategic vision that activists and their allies pursued in their fight against Willis. Next, I track the role of academic educational experts in converting these nodes of advocacy into a policy toolbox with a coherent ideology. Finally, I chronicle Chicago's first brick-and-mortar expressions of voluntary integration, illustrating both the egalitarian hopes that planners brought to their projects and the reassertion of the spatial

${ }^{7}$ Tracy Steffes, "Managing School Integration and White Flight: The Debate over Chicago's Future in the 1960s," Journal of Urban History 42, no. 4 (July 2016), 723; Anderson and Pickering, Confronting the Color Line, 336; and Danns, Desegregating Chicago's Schools, 20. 
and social class assumptions that had been baked into the magnet model. In addition to affording a ground-level view of the contingent development of the magnet concept - an exceptionally resilient innovation of America's desegregation era - the story told here provides an indispensable context against which the choice-and-accountability movements of the late twentieth century should be understood. The ideological embrace of choice as a reformist agenda at the end of the century required the administrative practice of choice during the desegregation era that preceded it.

\section{Part I: Origins}

As they transitioned from working-class white to middle-class black at the end of the 1950s, far South Side homeowner neighborhoods like Chatham, Avalon Park, and Burnside became shorthand for black accomplishment. ${ }^{8}$ On the pages of Chicago's black press, the college degrees, stable incomes, and tidy lawns south of 71st street were contrasted with white Chicagoans' views associating blacks with property devaluation and the decay of public amenities. ${ }^{9}$ Since the fall of racial covenant rules in 1948, black Chicagoans of means purchased their way out of the degraded conditions of the old black belt, while braving the threats to safety and dignity that smoldered in white neighborhoods. ${ }^{10}$ By 1960, only 21 percent of black Chicagoans lived inside the boundaries that sociologists St. Clair Drake and Horace Cayton had marked as their classic Black Metropolis. ${ }^{11}$ At the south end of the new, deconcentrated Black Metropolis, postal workers, bus drivers, and schoolteachers invested their savings and raised families in squat brick bungalows and scattered two-flats, while on prestige blocks, big names from Chicago's black commercial and cultural elite took up residence. Like their counterparts across America's postwar homeowner communities, mothers in these "Out South" neighborhoods built rich lives and relationships around their local elementary schools. Daily send-offs to school and weekly schedules of "PTA this and chaperone

${ }^{8}$ See Will Cooley, "Moving On Out: Black Pioneering in Chicago 1915-1950," Journal of Urban History, 36, no. 4 (July 2010) 485-506; Preston H. Smith II, Racial Democracy and the Black Metropolis: Housing Policy in Postwar Chicago (Minneapolis: University of Minnesota Press, 2012).

${ }^{9}$ Carl A. Fuqua, "Housing Discrimination in Chicago," The Crisis, June-July $1959,341$.

${ }^{10}$ Arnold R. Hirsch, Making the Second Ghetto: Race and Housing in Chicago, 19401960 (Chicago: University of Chicago Press, 1983).

${ }^{11}$ St. Clair Drake and Horace Cayton, Black Metropolis: A Study of Negro Life in a Northern City (1961; repr., Chicago: University of Chicago Press, 2015), 816-22. 
that" structured the labors and class identities for a generation of women on the far South Side. ${ }^{12}$

Beginning in 1958, however, Out South parents sensed that their status was eroding, as they watched class sizes rise above an average of forty per room. To manage enrollments, administrators converted libraries, art rooms, auditorium stages, and teachers' lounges into classrooms, eliminated enrichment programs, and filled staffing needs with substitute teachers. As rumors spread that schools might be placed on a double-shift, concerned parents sprang to action. Demands included requests for more staff, new construction, and demountable mobile classroom units to relieve overcrowding. For Out South parents, a return path from upward mobility was unacceptable. As mother and Burnside Elementary PTA president Alma Coggs and her neighbors wrote to the Chicago Board of Education in frustration, "THIS IS THE SPACE AGE [emphasis in the original]." 13

Here, the grievances of black homeowners dovetailed with the argument of civil rights lawyers and activists. By 1961, NAACP lawyers and Urban League researchers, frustrated with superintendent Willis's refusal to provide any data on racial characteristics in schools, had improvised their own "color-conscious" methods, shared data across their organizations, and begun to build a case against Chicago's stark educational inequities. ${ }^{14}$ Their research supported the same thesis that civil rights lawyers across the country were pursuing in legal challenges: de facto segregation produced harms equivalent to those enforced by de jure regimes in the South, and school districts were doing all they could to make things worse. ${ }^{15}$ In Chicago, where black schoolchildren made up 40 percent of enrollment in the public system, between 80 and 90 percent of them attended schools that were all black. Black pupils sat in more crowded classrooms in buildings with fewer special programs and were led by less

${ }^{12}$ Zerrie D. Campbell, interview by Adele Hodge, April 11, 2003, session 1, tape 2, story 2, The HistoryMakers Digital Archives, http://www.thehistorymakers.org/ biography/zerrie-d-campbell-39.

${ }^{13}$ Mary Grady et al. to Board of Education, Oct. 13, 1961, box 532, folder 3, Webb v. Board of Education of the City of Chicago Civ. No. 61c1569, D.C.N. D., Ill. (1961), case file, , National Archives and Records Administration (NARA)—Great Lakes Region, Chicago (hereafter cited as Webb Case File).

${ }^{14}$ Faith Rich, "De Facto Segregation in the Chicago Public Schools," The Crisis, 65, no. 2 (Feb. 1958), 87-93; Harold Baron, "An Equal Chance for Education" (1961), box 89, folder 965, Chicago Urban League Papers, Special Collections, Richard J. Daley Library, University of Illinois at Chicago (hereafter cited as CUL Papers).

${ }^{15}$ For use of "de facto," see Michael R. Glass, "From Sword to Shield to Myth: Facing the Facts of De Facto School Segregation," Journal of Urban History (Nov. 2016) 1197-1226., DOI: 10.1177/0096144216675473. 
experienced teachers. School overcapacity was not, as Willis maintained, simply the product of the massive surge in school-age population that Chicago experienced during the postwar era. In neighborhood schools like Burnside, crowded facilities resulted from what advocates called "Negro shuffling"-the flurry of attendanceboundary shifts within black residential enclaves that preserved a "sacrosanct" border between white and black residential areas. ${ }^{16}$

The fringe of the Out South middle-class black belt thus presented the geographic and demographic prerequisites for a legal challenge: a turf where white and black neighborhoods were contiguous and where an energized pool of willing litigants could be recruited. By the midpoint of the 1961-1962 school year, Out South parents' energy was undeniable. In August, they participated in the NAACP's "Operation Transfer," which encouraged black parents to show up at and attempt to enroll their children in out-of-area white schools. In September, they became the plaintiffs in Webb v. Board of Education of the City of Chicago (1963), brought by attorneys Paul Zuber and James D. Montgomery. ${ }^{17}$ And in January, they staged a sit-in at Burnside and filed a second lawsuit, the Burroughs case.

Central to civil rights legal strategies in the early sixties was the critique of the "neighborhood school," which, as Zuber and Montgomery put it in the Webb suit, was a policy aimed at "the containment of Negro pupils in Negro schools by means both ingenious and ingenuous." 18 In court, the argument never flew, and it was hardly certain that anyone beyond a committed core conceived of the neighborhood school as an artifact of state-sponsored racism. In fact, Out South parents had begun their advocacy in an effort to preserve the educational advantage that moving to a nice neighborhood was understood to ensure. In petitions to Willis and Mayor Daley, black "homeowner-families" worried that the "community standards" and class character of their area schools was under threat. ${ }^{19}$ While Willis's gerrymandering of attendance boundaries had insulated white schools from black enrollment, the same tactics collapsed the attendance boundaries between black homeowners

${ }^{16}$ Transcript of Proceedings, Burroughs $v$ Board of Education of the City of Chicago, Civ.No. 62c206, D.C.N.D. Ill. (1962), case file, box 42, folder 2, 22, NARA - Great Lakes Region (hereafter cited as Burroughs Case File).

${ }^{17}$ Webb v. Board of Education of City of Chicago (1961).

${ }^{18}$ Transcript of Proceedings, box 532, folder 3, Webb Case File.

${ }^{19}$ Statement of Edwin Turner, Dec. 16, 1959, Alma P. Coggs Affidavit, Exhibit E, box 42, folder 1, Burroughs Case File; and Statement of Mrs. Weltman, Dec. 16, 1959, Alma P. Coggs Affidavit, Exhibit D, box 42, folder 1 Burroughs Case File. 
and renters. As some put it bluntly at Board hearings, "we left overcrowded apartments to BUY our homes [emphasis in the original]."

It was this unique affront, manifest in the sudden inability to protect the privileges of middle-class community, rather than any positive desire for integrated schoolhouses, that led Out South parents to question their faith in the neighborhood school concept. In court, these contradictions left attorneys struggling to explain why, in the Burroughs case, Burnside parents had not demanded integration. Instead, they asked to remain at their all-black neighborhood school rather than be transferred, as Willis had mandated, to another all-black upper grade center. As Burroughs attorneys George Leighton and William Ming explained, the overstuffed classrooms at Burnside were links in the larger chain of gerrymandering, all animated by a goal of racial segregation. ${ }^{21}$ But this critique did not answer the question of where Americans' right to an education might be found. In telling moments, civil rights lawyers suggested that black parents, as persons harmed by segregation, had gained "the right to decide upon" questions of school quality and should thus be empowered to opt out of assignment to their local schools and choose "as to what they regard to be the best ... for their children." 22

The argument against the neighborhood school could bend in communalist or individualist directions. On the one hand, the antineighborhood school view suggested that the educational commons had been inequitably partitioned. To equalize education, the consumerist choices stored in residential property and tethered to local schools might need to be disaggregated and redistributed into a new common pool. On the other hand, ditching the neighborhood school implied an individual freedom that gave parents the right to choose where their child went to school, rather than having it chosen for them. The dismissal of both the Burroughs and Webb cases by mid1962 left no resolution to these questions. Meanwhile, just as Coggs was hitching her neighbors' frustrations to a citywide strike against de facto segregation, parents a mile and a half away were experimenting with another strategy.

Just north of 87th street, Chicago's gridded matrix of right angles sheared off into curving cul de sacs, promising families the feel of

${ }^{20}$ Statement of Thomas A. Marks, Dec. 16, 1959, Alma P. Coggs Affidavit, Exhibit C, box 42, folder 1, Burroughs Case File.

${ }^{21}$ Transcript of Proceedings, box 42, folder 2, 22, Burroughs Case File.

${ }^{22}$ Transcript of Proceedings, box 42, folder 2, 30, Burroughs Case File; Transcript of Proceedings, box 42, folder 2, 76, Burroughs Case File. The first quote is Leighton, the second is Ming. 
suburbia within the city limits. ${ }^{23}$ The Marynook neighborhood's four hundred single-family ranches and split-levels were home to only a handful of black residents in 1960, but white homeowners knew that more would come soon. For self-described liberals, who pointed often to their community's high concentration of college and graduate degrees, the inevitable arrival of black homebuyers needed to be met with the full neighborly force of the homeowners association. ${ }^{24}$ Going door-to-door, Marynook housewives worked to win residents over to the notion that black newcomers were "pleasant, orderly people," while praying that their white neighbors would be the same. ${ }^{25}$

If prejudice was an interpersonal matter, middle-class homeowners recognized that hopes for quality, integrated schools required a broader, concerted effort. In June of 1960, the Marynook School Committee convened a joint meeting of concerned parents from the greater Chatham-Marynook-Avalon Park area. The problem, neighbors agreed, was the local high school. Hirsch High School had become a "disciplinary barracks" rather than a place of higher education. Around dining room tables, the interracial team set to work inventing a vision of a regional high school. They cribbed the idea from a writeup by University of Chicago sociologist and education professor Robert Havighurst in the newsletter of the Citizens Schools Committee, a long-standing liberal watchdog on education issues. Havighurst offered what became a trope in his view of urban education. In the postwar era, he explained, higher-income families had moved to the suburbs and unskilled rural migrants had settled in the city. With the number of "culturally privileged" urban families dropping, and the ranks of the "culturally deprived" rising, city schools needed a new program of enrollment. If implemented soon, Havighurst hoped, Chicago could reverse these trends, which were bad both for children and the city. ${ }^{26} \mathrm{~A}$ frank distinction between the needs of the middle class and the working class called for a three-tiered "large district" high school system that used ability, rather than geography, to determine enrollment. Students would be sent to academic high schools where half

${ }^{23}$ Terry Sullivan, "How Marynook Meets the Negro," in The Changing Metropolis ed. Frederick I. Tietze and James E. McKeown (Boston: Houghton Mifflin, 1964), 144.

${ }^{24}$ Marynook parents "Presentation to Board of Education - Sept. 12, 1962," box 101, folder 1104, series III, CUL Papers.

${ }^{25}$ Sullivan, "How Marynook Meets the Negro," 3; and Naomi Brodkey, "They Chased the Gloom Peddlers Out of Marynook," New City: Man in Metropolis; A Christian Response, 2 (Dec. 15, 1963, 7.

${ }^{26}$ Marcia Lane Vespa, "Chicago's Regional School Plans," in Learning Together: A Book on Integrated Education, ed. Meyer Weinberg (Chicago: Integrated Education Associates, 1964), 120. 
of the students were college-bound, vocational high schools, or a "workstudy" program for the "slow learner" and "non-learner." 27

Activists from Marynook and Chatham ran with the idea, even earning a visit from Havighurst himself. In February 1961, the team unveiled the Chatham-Avalon-Marynook Plan (CAMP), a virtual reprint of Havighurst's recommendations. CAMP proposed abolishing existing boundaries for high schools in the greater southeast, replacing them with a consolidated attendance area, and redesignating schools as Academic, Vocational, Commercial, and Career Orientation, with a "student choice procedure" determining enrollment. ${ }^{28}$ As the sharp lines around "academic" and "career orientation" implied, however, schools might do as much choosing as the students. Promising "the death of the neighborhood school policy," regional-school proposals gave programmatic shape to the demand that the Chicago schools move toward integration. ${ }^{29}$ For this reason, along with the fact that it antagonized Willis, liberal and civil rights groups lined up to endorse regional plans. By the following year, both the Citizens Schools Committee and the Coordinating Council of Community Organizations (CCCO) released regional high school schemes for the greater southeast. ${ }^{30}$ But the regional school critique of the neighborhood school was distinct from that of civil rights activists. For liberals in the greater southeast, the problem with "neighborhood" as a unit of civic belonging was that it was drawn too tightly. "Community" or "region" expanded the physical dimensions of urban attendance areas while tightening access along lines of status. A plan like CAMP — scripted by Havighurst, embraced by black and white homeowners, and endorsed by civil rights advocatesprovided an early and instructive model of how to build a constituency for racial integration.

Despite the support that middle-class South Siders amassed behind their proposals, Willis showed little interest in adjusting attendance policies. Speaking "with a degree of candor" at Board hearings in September 1962, frustrated Marynook parents declared that the "abnormal social environment" at Hirsch High School, with fewer than thirty white students among its two thousand students, had become urgent. ${ }^{31}$ Setting aside community-scale solutions, parents now petitioned to send their children to Hyde Park High School on

${ }^{27}$ Robert Havighurst, "The Non-Learners: The Schools' Number One Problem," Chicago's Schools: Official Organ of the Citizens Schools Committee, 27, no.1 (Sept. 1960), 3.

${ }^{28}$ Vespa, "Chicago's Regional School Plans," 118.

${ }^{29}$ Vespa, "Chicago's Regional School Plans," 119.

${ }^{30}$ Vespa, "Chicago's Regional School Plans," 120-122.

${ }^{31}$ Marynook parents, "Presentation to Board of Education - Sept. 12, 1962." 
a case-by-case basis. At Hyde Park, black students also outnumbered whites by large margins, but the academic program signaled the high caliber parents sought in a college-focused community. In asking to enroll their children in a majority-black high school, Marynook parents presented their integrationist bona fides. But their proposal was also a threat: unless "college preparatory education of the highest order" was made available, they would have to leave for another school district, precipitating the turnover of yet another South Side neighborhood. ${ }^{32}$

Arguments about the necessity of retaining white property and white families in the greater southeast resonated with Board of Education members, not least because several lived there. ${ }^{33}$ By November 1962, a special Board committee endorsed an experimental plan to test the basic premises of voluntary, selective transfer. As the committee chair explained, these innovations held potential benefits that were often thwarted by the "rigidity of plans based on strictly geographical considerations." ${ }^{4}$ While the Board warmed to selective integration, the direct action movement against overcrowding that began at Burnside expanded, joined by neighborhood organizations, clergy, student activists, and civil rights groups. Willis responded with a "permissive transfer plan" for students in overcrowded schools. When only a few parents applied for transfers, Willis took it as proof that Chicagoans, black and white, accepted the concept of the neighborhood school. ${ }^{35}$ At Board hearings in November and December of 1962, dozens of citizen groups said otherwise. Announcing that it was "time to stop building for ... containment," parents and their advocates declared Willis's transfer plan "a farce and a disgrace," demanding aggressive open-transfer programs and funding for student transportation. ${ }^{36}$

${ }^{32}$ Marynook parents, "Presentation to Board of Education - Sept. 12, 1962."

${ }^{33}$ Steffes, "Managing School Integration," 13.

${ }^{34}$ Citizens Schools Committee Report, Dec. 1962, box 22, folder 345, 3-4, Industrial Areas Foundations Papers, University of Illinois at Chicago Special Collections (hereafter cited as IAF papers).

${ }^{35}$ Citizens Schools Committee Report, Nov. 1962, box 22, folder 345, IAF papers.

36 "Citizen Testimony on School Integration," Integrated Education (Jan. 1963), 22; "School Budget Hearing," Chicago's Schools 29, no. 2 (Jan. 1963), 2; "Statement by H. B. Law to the Chicago Board of Education," Nov. 19, 1962, box 22, folder 345, IAF papers; and "Chicago Teachers Union Position on Human Relations Within Chicago Public Schools," June 8, 1962, box 1, folder 2, Cyrus Hall Adams Papers, Chicago History Museum (CHM) Research Center (hereafter cited as Adams Papers). 
By summer of 1963, Chicago's school-protest culture had made its mark on the city's broader racial politics. In July, during the NAACP's meeting in Chicago, Mayor Daley had hoped to make a gesture of solidarity with moderate civil rights leaders, but was instead rebuked and heckled. Meanwhile, Congress of Racial Equality (CORE) members expanded their agitation, including a regular schedule of sit-ins at the Board of Education. ${ }^{37}$ As a vehicle for the critique of de facto segregation, the confrontation with Willis proved exceptionally effective. At pickets and lie-ins across the city, activists converted research data and legal arguments into snappy, enduring slogans. "Willis = Wallace" summed up activists' equation of Northern and Southern segregationism. By the end of the summer, three demountable classroom units - the same kind that Burnside Elementary parents had politely requested in 1959-had been burned in protest. For generations, the metal trailers were called "Willis Wagons," and the summer of 1963 was recalled as a moment of black awakening in Chicago.

In mid-August, Willis presented plans for a "selective permissive transfer program," authorizing transfer permits for high school students who ranked in the top 5 percent of academic achievement at their schools. The plan supplemented efforts to create accelerated programs for Chicago's "gifted" students, which some judged as lagging behind suburban schools. ${ }^{38}$ The proposals emitting from the far South Side added to growing pressure on school administrators to systematize the means by which the nation's brightest were prepared for careers that required advanced degrees and specialized skills. As experts advised, education at all levels - college preparatory, technical, and vocational-required more rigorous screening and tracking. ${ }^{39}$

Willis presented the transfer program as unconnected to the civil rights battle roiling the city. What followed was just the opposite. In late August, as Zuber announced that a refiled Webb suit had reached an out-of-court settlement, the Board approved Willis's transfer plan, creating a list of "sending" schools, from which invited students of merit could elect to transfer to a receiving high school of their choice. In Marynook and Chatham, parents with hopes of sending their children to Hyde Park or South Shore High Schools were excited to see Hirsch High School on the list of senders. But when a single black

${ }^{37}$ Anderson and Pickering, Confronting the Color Line, 111-13.

38 "Establish Four Gifted Child Demonstration Centers at Carver, Bryn Mawr, Tesla, and Bell," News of the Chicago Public Schools, 1, no. 2 (March 1964), 5.

${ }^{39}$ US Panel of Consultants on Vocational Education, Education for a Changing World of Work (Washington, DC: US Dept. of Health, Education, and Welfare, Office of Education, 1962). 
family from Hirsch was spotted visiting Bogan High School, sited in an all-white Southwest Side homeowner community, area parents mounted an immediate resistance, which the press covered with gusto. Bogan parents took their protest downtown, where they staged pickets and demanded meetings, which administrators happily granted. ${ }^{40}$ Within weeks, Willis eliminated fifteen high schools from the list of receivers, including Bogan.

The "bigots at Bogan" quickly personified Chicago's unenlightened white resistance, and remained at the epicenter of anti-integration politics for the next two decades. ${ }^{41}$ For advocates of integration, the transfer debacle supplied the perfect illustration of their thesis: Willis was the front man for racism in the urban north. Segregationism was segregationism, whether fuming beneath housewives' curlers or buttoned up in the gray suit of urban technocracy. A mobilized base of urban segregationists also made a more telegenic target than "de facto" constructs, as open housing marchers in Marquette Park discovered three years later. ${ }^{42}$

While Southwest Side residents rejoiced at the revision of the receiving school list, racial liberals in Marynook eight miles to the east despaired. Among the schools removed from the list were South Shore and Hyde Park High Schools, where several high achievers from Marynook hoped to attend. Not to be discouraged, Marynook lawyer and father Hugh Brodkey, along with an interracial cohort of four neighbors, filed suit against Willis. School officials, Brodkey argued, in counseling high-achieving students to consider leaving their current high school, had conferred on them "certain rights" to an "educational opportunity commensurate with their ability," which Willis now violated. ${ }^{43}$ On October 3, in Willis's first and only loss in the courts, the judge agreed and issued an injunction compelling the superintendent to transfer four students from Hirsch to the high schools of their choice. ${ }^{44}$ When a deputy sheriff attempted to serve the superintendent with the injunction at the Board offices, Willis slipped out and headed home, where the chief deputy bailiff tracked him down the following afternoon. Rather than submit to the order, Willis announced his

40 "Few Students to Transfer, Willis Says: Reports Many Prefer Own Schools," Chicago Tribune, Sept. 12, 1963, 6.

${ }^{41}$ Lillian S. Calhoun, "Bogan High School NOT Crowded," Chicago Defender, Sept. 30, 1963, A2.

${ }^{42}$ Marquette Park joined Bogan as an emblem of Southwest Side racism in the summer of 1966, when white counterprotesters struck Martin Luther King with a rock during an open housing march.

${ }^{43}$ Proceedings, McCormick v. Willis, Superior Court of Cook County, Civ. No. 63s26857 (1963) Case File, Archives of the Clerk of the Circuit Court of Cook County, 3, 15 (hereafter cited as McCormick Case File).

${ }^{44}$ Order, McCormick Case File. 
resignation, escalating a gifted-student transfer program into an institutional crisis. $^{45}$

Civil rights groups rejoiced, but their moment was fleeting. Business leaders and Willis's allies on the Board scurried to undo his departure. Two days later, the Board voted not to accept Willis's resignation and formed a "peace-making" committee. By mid-month, Willis was back on the job, expressing how "deeply touched" he was by gestures of support. ${ }^{46}$ Chicago's civil rights coalition's response was swift and spectacular, green-lighting a plan hatched by Lawrence Landry, a University of Chicago graduate student and leader of the Chicago Area Friends of the Student Nonviolent Coordinating Committee (SNCC). The plan - an unprecedented citywide boycott of the schoolsexceeded the organizers' expectations. On Freedom Day, October22, 1963 , nearly 225,000 students stayed home, while 10,000 picketers massed on the streets downtown, calling for Willis's removal. ${ }^{47}$

The pivot around which Chicago's civil rights history turned, oddly enough, was a middle-class demand to pursue ability-grouped college-preparatory options for the "talented." For boycott organizers, the mass strike against the schools was only partially about education. The larger accomplishment - projecting a vision of mass political participation that challenged Daley's power structure and the city's black political establishment-impressed Martin Luther King Jr. and the Southern Christian Leadership Conference (SCLC) enough to bring a campaign to Chicago. With the Chicago Freedom Movement launched from a West Side slum in 1966, the move to an antipoverty emphasis was complete. As the politics of organizing the poor took center stage, technocratic talk of school attendance policy diminished from view. Among the nine demands that movement leaders brought to their summit meeting with Mayor Daley, schools were nowhere to be found. While activists' focus moved away from education policy, the experiences of the early 1960s highlighted the rising power of schools as sites of political organizing, but with an ambivalent position toward interracial education. Integration was one strategy some black parents used to defend the spatial and educational prerogatives of middle-class parenthood. Linking fortunes with a broad-based movement that included Chicago's poorest ranks was another. While the civil rights movement provided the unique context under which both strategies could be pursued at once, it was unclear how long these dual coalitions could be maintained.

\footnotetext{
45 “Dr. Willis Resigns," Chicago Tribune, Oct. 5, 1963, N10.

${ }^{46}$ Benjamin C. Willis to the Board of Education, statement, Oct. 16, 1963, box 1, folder 4, Adams Papers.

${ }^{47}$ Anderson and Pickering, Confronting the Color Line, 116-20.
} 
The regional schemes and transfer plans also provoked a rift among white Chicagoans. The press cast the contrast between white supporters of integrated schools and the Southwest Side resistance as the difference between the racially tolerant and the morally ignorant. But racial tolerance was as much a political bargain as a moral awakening. In the urban context, the rising concern with college prep had provoked a reconsideration of the durable postwar arrangement that linked educational opportunity with the property values and political privileges of racially homogenous enclaves. In a moment of metropolitan transformation, the urban middle class seemed to realize, educational credentials might be a commodity worth protecting just as much as, and perhaps independent of, residential property. In pursuing bonds of interracial "community" over the boundaries of "neighborhood," white liberals hooked civil rights arguments for integrated schools to their desire to protect a college-bound future for their children, all while hedging against the decline in land values that transition represented in a racialized real estate market.

\section{Part II: Synthesis}

Throughout the era of Chicago's civil rights agitation, education experts served as auditors and investigators for various panels and commissions. Lending their technical expertise and sociological imagination to the critique of Willis, these scholars distilled the compatible elements of civil rights activism and liberal homeownerism into a coherent but constrained vision of integrated education. As public intellectuals, these liberal academics became agents within the very civic ecosystem they studied, seeking a place of influence between the state and a fractious civil society. But Willis's confidence in ignoring these independent auditors indicated that, for as long as he held office, the education experts' work was ceremonial, bestowing a blue-ribbon prestige to the civil rights arguments against segregation while exerting little in the way of political leverage. Instead, their work staked the outer limits of Chicago's integrationist imagination, drafting a blueprint for a post-Willis era.

The first such blueprint came in 1962, when the US Commission on Civil Rights contracted Northwestern University law professor John E. Coons to report on Chicago's school segregation fight. Because Willis insisted that no racial data was kept on students, the law professor relied on estimates by local civil rights activists. ${ }^{48}$ For as "incomplete" as Coons was forced to be in his report, he affirmed the findings of Harold

${ }^{48}$ John E. Coons, interview with the author, March 8, 2015; and John E. Coons, "Chicago" in Civil Rights U.S.A. Public Schools Cities in the North and West (Washington, DC: US Commission on Civil Rights, 1962), 182. 
Baron of the Urban League and Faith Rich of the NAACP.49 Coons's report, published in the wake of the October 1963 boycott, was embraced by Chicago's civil rights coalition. ${ }^{50}$ Unlike Rich and Baron, however, who had begun to elaborate Zuber's critique of the neighborhood school, Coons resisted blaming Willis, describing school segregation as a "product of other forces," the most urgent being "racial transition." The problem, Coons believed, was accelerating; schools with a 30 percent black enrollment were likely to become all-black within a year. ${ }^{51}$

Puzzling his way through the resegregation problem, Coons concluded that both quantitative and qualitative caps on black enrollment were necessary to engineer stably integrated student populations. To hold black enrollments below the tipping point that was thought to trigger white withdrawal, Coons proposed a benign racial quota. In the name of convincing parents that the schools would maintain their standards, Coons advised that transfer plans should target "students whose background and personal characteristics are not poles apart from the children in the receiving schools." ${ }^{52}$ As the tumult following Willis's selective plan showed, South Side support for such programs existed, but political opposition stood coiled to strike. Coons's conclusions revealed the three elements that ultimately formed the basis of urban school integration in the post-civil rights era: choice, quotas, and selectivity. Choice was unleashed by open attendance boundaries and permissive transfer. Quotas served as blocks against rapid racial succession. Selectivity was contemplated as a strategic elitism, aimed at recruiting students whose academic success could be promoted as a success for integration.

Coons's conclusions found elaboration when, at the end of 1963, the out-of-court settlement in the Webb case triggered the formation of a five-man advisory panel, chaired by University of Chicago sociologist Philip Hauser. ${ }^{53}$ In their March 1964 report, the panel endorsed the civil rights critique of Willis and condemned the Board's inaction on segregation, declaring that there was "nothing sacred" in the neighborhood school idea. The drama of school integration, Hauser predicted, required "unprecedented mobilization of community resources and unprecedented co-operative action." ${ }^{54}$ Like Coons, Hauser stressed

${ }^{49}$ Coons, "Chicago," 216-27.

${ }^{50}$ Anderson and Pickering, Confronting the Color Line, 95-96.

${ }^{51}$ Coons, "Chicago," 186.

${ }^{52}$ Coons, "Chicago," 233.

${ }^{53}$ Philip M. Hauser, et al., "Report to the Board of Education of the City of Chicago by the Advisory Panel on Integration of the Public Schools," March 31, 1964, 2; and Casey Banas, "Report Due Tuesday on Study of Schools," Chicago Tribune, March 29, 1964, E20.

${ }^{54}$ Hauser, et al., Report to the Board of Education, 26. 
the dangers that white "exodus" posed to the promise of integrated schools. Warning that integration could soon "become simply a theoretical matter," Hauser's team projected that white schoolchildren, who were already less than half of the system's elementary-age population, would constitute only 35 percent of overall enrollment by $1970 .{ }^{55}$ The tactics Hauser recommended-merging some contiguous neighborhood attendance areas to form enlarged "clusters" as steps toward citywide open enrollment for high schools-expressed, in technical terms, the need to link the moral mission of integration to the civic goal of arresting white flight. ${ }^{56}$ In an interesting emphasis, the Hauser panel stressed that its "primary concern" was "to protect and progressively expand the freedom of individual choice [emphasis in the original]." 57 The stress on choice carried none of the market-driven meaning that it would pick up later in the century. Rather, choice was a term of art that reflected the argument of black parents and their lawyers - like Coggs and Zuberwho saw the Board denying their right to freely choose where their children attended school. It also rang true with white liberals-like those in Marynook - who believed that a community should be empowered to manage an integrated future. At the same time, choice language reassured less liberal Chicagoans - like the parents at Bogan — who opposed policies that compelled anything. Most fundamentally, choice was a practical means to achieve the integration that experts deemed feasible in a residentially segregated city without a court order. There could be no such thing as an integrated school unless parents were induced to choose not to attend their neighborhood school.

Meanwhile, Havighurst, Hauser's colleague in the sociology department at the University of Chicago, was already several months into an exhaustive survey of the Chicago school system. Joining other districts in a national moment of self-assessment, the Board of Education had authorized creating a Survey Committee in 1961 and appointed Havighurst to chair the team in $1963 .{ }^{58}$ A published authority in his field and an active member of liberal citizens' groups, Havighurst characterized his work in holistic terms. What good were sociologists, he asked, "who can write good critiques, but cannot find their way around in a real community[?]"59 Havighurst certainly knew his way around real communities. Whether appearing with

\footnotetext{
${ }^{55}$ Hauser, et al., Report to the Board of Education, 6, 12.

${ }^{56}$ Hauser, et al., Report to the Board of Education, 27-29.

${ }^{57}$ Hauser, et al., Report to the Board of Education, 26.

${ }^{58}$ Chicago's Schools 29, no. 2 (Jan. 1963), 3.

${ }^{59}$ Robert Havighurst to Francis Chase, April 6, 1955, box 22, folder 7, Robert J. Havighurst Papers, University of Chicago Special Collections Research Center (hereafter cited as Havighurst Papers).
} 
Zuber at publicity events for the Webb case or sitting in on planning meetings in Marynook living rooms, Havighurst grasped the place that racially liberal, college-focused, middle-class parents had taken in education politics. In Havighurst's view, these groups, if coached, could reinvent schools and save the city.

Because of Havighurst's public alliance with Chicago's civil rights coalition and his stand against the neighborhood school, Willis opposed him at every turn, while liberal and civil rights groups supported him. ${ }^{60}$ On integration, Havighurst deferred to the Hauser committee, but his five-hundred-page report rendered a fuller picture of schools as stitched into the fabric of social life, interdependent with the city and metro region's postwar socioeconomic changes. ${ }^{61}$ Race, class, and migration, Havighurst argued, had sorted students into an irrational typology of "high-status schools, main-line schools, common-man schools, and inner-city schools." ${ }^{2}$ While Havighurst recommended a flood of extra resources for the inner city, he emphasized the need to intervene in the "more 'favored' types of schools" as well, where the chances of "social urban renewal" were highest. ${ }^{63}$ Depending on "the consensus of sentiment," Havighurst advised, the Board "should carry on practices to promote integration more vigorously in some areas of the city than in others [emphasis in the original]." 64 In the right neighborhoods, Havighurst recommended "home rule," where an empowered, enlightened community could redraw boundaries for high-quality, integrated high schools. ${ }^{65}$ Havighurst proposed that three regions, all clinging to the shores of Lake Michigan, be adapted to an "Area Plan for Neighborhood Stabilization." 66 The efforts afoot Out South and in the Southeast earned them a spot on Havighurst's map. In the rest of the city, the neighborhood school concept could remain intact, unthreatened by "forced social change." 67

Many Chicagoans saw the Coons, Hauser, and Havighurst reports the way that Willis did: as an assault on the neighborhood school and as

\footnotetext{
${ }^{60}$ Paul West, "Many Groups Back School Survey Choice," Chicago Tribune, April 29, $1963, \mathrm{~B} 17$.

${ }^{61}$ Robert J. Havighurst, The Public Schools of Chicago: A Survey for the Board of Education of the City of Chicago (Chicago: Chicago Board of Education, 1964), 10-11.

${ }^{62}$ Havighurst, The Public Schools of Chicago, 145.

${ }^{63}$ Havighurst, The Public Schools of Chicago, 182.

${ }^{64}$ Havighurst, The Public Schools of Chicago, 383, 379.

${ }^{65}$ Havighurst, The Public Schools of Chicago, 379; and Robert J. Havighurst, "A Positive Approach" (speech, Citizens Schools Committee, Fall 1964, box 27, folder 3, Philip M. Hauser Papers, University of Chicago Special Collections Research Center (hereafter cited as Hauser Papers).

${ }^{66}$ Havighurst, The Public Schools of Chicago, 383-90.

${ }^{67}$ Havighurst, The Public Schools of Chicago, 379, 381.
} 
powerful tools for civil rights activists. Coons preferred to turn down the heat, noting that most press coverage of his findings was akin to "throwing just the conclusions of the Kinsey Report at the public."68 Anti-integrationists sent hate mail to the University of Chicago, condemning the communistic excesses of "Hauserism," and the "useless sociologists" "who contribute nothing." ${ }^{99}$ As public defenders of their work, university-based education experts had mixed success. Hauser was often indelicate, and local media relished it when he let slip his disdain for the public. Booed by white parents at Bogan High, Hauser snapped that many in the crowd could use more schooling. ${ }^{70}$ In a speech at the City Club of Chicago, he called the Illinois General Assembly "a hillbilly legislature." 11 Havighurst proved a smoother operator, boiling his message down to "the urban community school philosophy," which appeared to improve, rather than replace, the neighborhood school concept. ${ }^{72}$ In contrast to Willis's "four walls school," which promised only to do what it could with the raw material that was forced into its classrooms, Havighurst called for schools that interacted with neighborhoods to "make the city exciting and attractive." 73

For all their boosting of integrated education, Coons, Hauser, and Havighurst worked under especially cramped conditions. Willis was but the most obvious cog in the legal and political machinery that narrowed the scope of school desegregation in Chicago. On the legal front, the latest court decisions dimmed the hopes that Zuber and his colleagues had entertained just two years prior. ${ }^{74}$ Memos between the city's corporation counsel suggested that racial quotas might not be upheld in the courts but that the neighborhood school would be. ${ }^{75}$ With the neighborhood school concept insulated from court challenge,

\footnotetext{
${ }^{68}$ John Madigan, "Standpoint," television transcript, Dec. 3-4, 1962, box 22, folder 348, IAF Records.

${ }^{69}$ Letters, undated, box 6, folder 4, Hauser Papers; and Chesly Manly, "Dr. Havighurst Has Heard Pinko Before," Chicago Tribune, May 5, 1963, N1.

${ }^{70}$ Letter to Hauser, unsigned, box 6, folder 4, Hauser Papers.

71 "Hauser Sees Legislators as Hillbillies," Chicago Tribune, April 14, 1964, 11.

${ }^{72}$ Havighurst, "A Positive Approach."

${ }^{73}$ Lois White, "Havighurst Reviews His Own Report: Chicago Schools Get an F," Chicago Daily News, Oct. 8, 1966.

${ }^{74}$ J. L. W. "Racial Imbalance in the Public Schools: Legislative Motive and the Constitution," Virginia Law Review 50, no. 3 (April 1964), 464-534; Paul Auster, "DeFacto Segregation" William and Mary Law Review 6, no. 1 (Jan. 1965), 41-57; and Owen M. Fiss, "Racial Imbalance in the Public Schools: The Constitutional Concepts," Harvard Law Review 78, no. 3 (Jan. 1965), 564-617.

${ }^{75}$ John O. Tuohy to John C. Melaniphy, memo, April 2, 1964, box 89, folder 973 , CUL Papers.
} 
the CCCO invited federal intervention, filing a Title VI complaint with the Department of Health, Education, and Welfare (HEW). For a flash of five days in 1965, HEW affirmed the complaint by blocking $\$ 32$ million in new funding to Chicago's schools, but this initiative was quickly flattened. A quick meeting between Daley and President Lyndon B. Johnson unfroze the funds, returning Chicago's integration initiatives to local control. ${ }^{76}$ By 1965 , with no federal pressure, no court mandate, and Willis back on the job, Hauser and Havighurst were, as the Urban League put it, "Two Reports on A Shelf."

In the summer of 1966, Willis finally announced his retirement. Among those who had battled Willis, the new superintendent, James Redmond, was met with cautious optimism. Redmond attempted to reflect the hope of a new start, but privately confessed "feeling[s] of inadequacy" about the job. ${ }^{78}$ While Redmond shopped for a home, the National Guard patrolled West Side streets after several nights of rioting. Martin Luther King Jr., who had moved to town in January, undertook a grueling schedule of rallies, which, on more than one occasion, white residents greeted with rocks and bricks. At an August "summit" meeting, King and Daley competed to stage-manage an urban crisis in motion. ${ }^{79}$ In a January 1967 report sent to Redmond and the Board, the US Office of Education highlighted areas of concern under Title VI of the Civil Rights Act of 1964 and instructed Redmond to develop integrated, innovative schools with broad attendance areas. ${ }^{80}$

With pressure mounting, Redmond secured a HEW grant and convened a working group of experts, including Coons, to conceptualize a new system of student assignment. The report, known as the "Redmond Plan," struck the same mix of integrationist mission and socio-civic cynicism that had informed the Coons, Hauser, and Havighurst reports. On "those elements of the white population that are least prepared," the team advised Redmond to "avoid forcing the

\footnotetext{
${ }^{76}$ Stephen D. London, "Business and the Chicago Public School System, 18901966" (PhD diss. University of Chicago, 1968), 137-38.

77 "Hauser and Havighurst: Two Reports on a Shelf," box 51, folder 17, Lincoln Park Conservation Association Records, DePaul University Special Collections (hereafter cited as LPCA Records).

${ }^{78}$ Casey Banas, "Want to Prove Big City School System Isn't Doomed" Chicago Tribune, May 12, 1966, 6; and James F. Redmond to Robert Havighurst, May 17, 1966, box 28, folder 12, Havighurst Papers.

${ }^{79}$ Anderson and Pickering, Confronting the Color Line, 237-69.

80 "Report on Office of Education Analysis on Certain Aspects of Chicago Public Schools Under Title VI of the Civil Rights Act of 1964," Jan. 1967, box 212, folder 1, 7-10, Havighurst Papers.
} 
extreme pressures of school integration." ${ }^{81}$ In the short term, the team recommended expanding permissive transfer, limited busing of black students, and quotas on black enrollment in schools on the racial borderlands. As planners warned, only a "fraction of ghetto youngsters" would see racial change in their classrooms. ${ }^{82}$ These conclusions followed from what other Chicago-based demographers predicted. Concurrent with the Redmond Plan working group, a second team, staffed by members of the Real Estate Research Corporation (RERC), compiled population data into a set of projections on school enrollment for the next half decade. In their report, RERC departed from Willis-era pretenses to color-blindness, warning that with a sustained "decrease in the [white] birth rates and the out-migration of white females of child-bearing ages" from the city, "the intensive transition" of neighborhoods from white to black could be expected to continue. $^{83}$

If the Redmond team's short-range proposals lowered expectations against confounding demographics, their long-term goals were hardly conservative. As part of a "thirty-year undertaking," the working group called for a citywide system of integrated "educational park" complexes, a high-tech novelty in facilities design, which would mass kindergarteners through community college students on a single campus and deploy resources on a shared-use system. ${ }^{84}$ While the educational park model awaited feasibility studies, the team proposed that within three to seven years, nuclei could be constructed around something called the "magnet school." ${ }^{85}$ For Redmond's team, the magnet school meant wide attendance boundaries and a lottery to ensure integration, "outstanding" educational programs, and provisions for transportation. Beyond these criteria, the idea was a blank slate. ${ }^{86}$

As administrators were well aware, Chicago already operated specialized high schools with enlarged attendance boundaries, but they

${ }^{81}$ James F. Redmond, Increasing Desegregation of Faculties, Students, and Vocational Education Programs (Chicago: Board of Education, 1967), B-17, B-19.

${ }^{82}$ Redmond, Increasing Desegregation, B-16.

${ }^{83}$ Anthony Downs et al., Projections of Population and School Enrollment by Community Area for the City of Chicago, 1970 and 1975 (Chicago: Real Estate Research Corporation, 1968), II-5, IV-7.

${ }^{84}$ Civil Rights Commission, Education Parks: Appraisals of Plans to Improve Educational Quality and Desegregate the Schools (Washington, DC: U.S. Commission on Civil Rights Clearing House, 1967), 1-13; and U.S. Office of Education, Pacesetters in Innovation: Fiscal Year 1966, Title III Supplementary Centers and Services Program, Elementary and Secondary Education Act of 1965 (Washington, DC: Government Printing Office, 1966), 34.

${ }^{85}$ Redmond, Increasing Desegregation, B-24.
${ }^{86}$ Redmond, Increasing Desegregation, B-6, B-9, B-24, B-26. 
still tended to be racially marked. On the North Side, technical high schools like Lane enrolled only a handful of black students, while on the South Side, Lindblom and Chicago Vocational High School were transitioning toward all-black enrollments and unable to draw from beyond their immediate surroundings. Well-regarded vocational schools, like Dunbar on the South Side and Lucy Flower on the West Side, pulled motivated black students from well beyond their perimeter, but drew no white pupils. Only Jones Commercial, an all-girls office-work school in the South Loop, succeeded in hosting an integrated student population that was drawn from across the city. ${ }^{87}$

In Chicago, novelty concepts like the "magnet school" and the "educational park" were vessels into which the lessons of the Willis era were concentrated and pitched anew, promising the first material response to the civil rights demand to eliminate the neighborhood school and giving hope to white communities that stabilization was around the corner. With expanded attendance boundaries, these new structures could draw students from around the segregated city to neutral turf. Tight racial quotas would guarantee places for black students while easing white fears of racial inundation, and the hype generated around new facilities and innovative programs would "anchor the whites," ensuring that black kids had someone to integrate with. The Redmond Plan's most remarkable proposal called for creating ten lakefront peninsulas, each housing a massive educational compound for twenty thousand students. ${ }^{88}$ While these images tickled the civic-futurist imagination, they also revealed just how skeptical civic leaders were about the prospects of racial harmony; the best place they could imagine for integrated schools was on Lake Michigan.

At the center of the Redmond Plan was the argument black civil rights litigants and academic education experts put forward: the neighborhood school concept would have to be abandoned in order to give black schoolchildren a fair shot at urban education. But this conclusion had been joined to an aggressive agenda aimed at the open-minded white middle class. Thus, with expanded opportunity for those on the city's social margins as the original problem, experts endorsed programs designed with people like themselves in mind. Against their own worst fears, proponents of voluntary desegregation also reimagined interracial peace as sophisticated pro-growth weaponry in the tussle over metropolitan resources. As anchors of community, highstatus integrated schools might prevent the feared slide in land values that followed middle-class flight. As specialized incubators of a

\footnotetext{
${ }^{87}$ Redmond, Increasing Desegregation, C-23-C-29; maps 5-13.

${ }^{88}$ Redmond, Increasing Desegregation, B-17, B-24, B-25, B-28.
} 
multiracial white-collar labor force, proposals responded to the worry that the city's human capital resources were being squandered by irrational and inefficient schooling. This meant, on the one hand, purging the school system of its racist assumptions about the capacities of black children and, on the other, tightening educational institutions' abilities to identify those students whose superior talents were being lost amid an ever-larger sea of the "disadvantaged." Only magnet schools assured such a wide range of benefits in a single package.

But the academic education synthesis left fundamental questions unresolved. Was desegregation an egalitarian "opening" of the city, in which clout, class, and culture could be shaken loose from their uneven accumulations and redistributed across the landscape? Or was it a more pragmatic tinkering with the city's native norms, in which racial balance, even if only feasible in a few middle-class schoolhouses, might provide a prototype for improved social relations? As Hauser, Havighurst, and the designers of the Redmond Plan saw things, the latter might provide the means by which the former could ultimately be achieved. However, as Coons warned before leaving for a teaching position at UC Berkeley in 1968, "Public policy, particularly in Chicago, has a characteristic manner of being substantially less than what is envisioned by its planners." 89

\section{Part III: Realization}

The summer disorders of 1967 cast an unmistakable cloud over legal and administrative integration in the urban North. Prominent voices like sociologist James Coleman declared the end of an era. The coalition of white liberals and civil rights groups that had pushed for school desegregation had splintered. In Coleman's version, demands for "black control of black schools" had dampened the integrationist mission within civil rights groups. White enthusiasm for integrated schools had always been limited, and the riots seemed to confirm the wisdom of those who had fled the cities rather than stay and "manage" integration. Any new moves, Coleman warned, were "now confronted with groups on both sides of the racial line who find nothing of value, and something of harm, in racial integration of schools." 90

In Chicago, some of Coleman's generalizations applied. White homeowners continued to leave the South and West Sides. As the

${ }^{89}$ John E. Coons, "Chicago" in Affirmative School Integration: Efforts to Overcome De Facto Segregation in Urban Schools, ed. Roscoe Hill and Malcolm Feeley (Beverly Hills: Sage Publications, 1967), 88.

${ }^{90}$ James S. Coleman, "Three Phases of School Integration" in Hill and Feeley, Affirmative School Integration, 6. 
color line moved, schools succumbed to new rounds of interracial violence. ${ }^{91}$ Elsewhere, the Black Power movement inspired new forms of organizing on educational issues, often with an emphasis on cultural self-definition..$^{92}$ Meanwhile, Redmond's December 1967 announcement of a limited busing program spurred another round of white protest, encouraged by politicians on the Southeast, Northwest, and Southwest Sides. ${ }^{93}$ Behind headlines of racial polarization, however, remnants of the interracial alliance that had championed integrated schools stood ready to unite around whatever the new superintendent and his "magnet" idea could deliver. As the Redmond Plan promised, if one magnet prototype could succeed, a "halo effect" would follow, ensuring more such schools. ${ }^{94}$

Nowhere had the Marynook thesis-that the neighborhood school might need to be jettisoned in order to save the neighborhood-proven more compelling than in South Shore. A high-status, lakefront community for what one resident jokingly recalled as "Lace Curtain Irish and Uptight Middle-Class Jews," the neighborhood had, by the mid-1960s, become the new front line of racial transition. ${ }^{95}$ Like their allies in Marynook and the Social Sciences building at the University of Chicago, the South Shore Commission (SSC), a membership-driven organization committed to "managed integration," believed that the future of the South Side ran through integrated schools. Throughout the decade, the SSC's interracial membership increased, and it raised funds and leveraged its influence in support of multiple school-centered initiatives. ${ }^{96}$ At the base of this activism was the problem that Coons, Hauser, and Havighurst had put at the center of their research and that a Chicago Daily News headline

${ }^{91}$ See "High School Disorders," 1967-68, Municipal Reference Collection Clippings File, Harold Washington Library Center, Chicago.

${ }^{92}$ John F. Lyons, Teachers and Reform: Chicago Public Education, 1929-1970 (Urbana: University of Illinois Press, 2008); Dionne Danns, "Chicago High School Students' Movement for Quality Public Education, 1966-1971," Journal of African American History 88, no. 2 (Spring 2003), 138-50; and Elizabeth Todd-Breland, A Political Education: Black Politics and Education Reform in Chicago Since the 1960s (Chapel Hill: The University of North Carolina Press, 2018).

93 "Parents Map a Protest on Busing Plan," Chicago Tribune, Jan. 5, 1968, 2; "1,700 Attend Busing Parley at Steinmetz," Chicago Tribune, Feb. 16, 1968; and "Hanson Pk. Busing Protest Draws 2,000," Chicago Tribune, Feb. 26, 1968, 9.

${ }^{94}$ Redmond Increasing Desegregation, E-8.

${ }^{95}$ Harold Baron, interview with the author, Dec. 15, 2015; and Harvey Luskin Molotch, Managed Integration: The Dilemmas of Doing Good in the City (Berkeley: University of California Press, 1972), 43-51.

${ }^{96}$ Shirley Cayer, "Schools Echo the Crisis," Daily Calumet (Chicago), Sept. 26, 1966 in South Shore Commission Records, box 1, album 1, Chicago History Museum Research Center (hereafter cited as SSC Records). 
covering the SSC's activities had captured in the bluntest terms: "Negroes, Yes, but How Many?"97

For SSC president Paul Hartrich, Superintendent Redmond's plan for an "intra-community pilot program," announced in the closing days of 1967, was the fulfillment of a dream long deferred. He had waited while Willis shelved or trimmed every plan they endorsed. Now, with old plans ready to jump off the shelf and onto Redmond's desk, Hartrich bundled up and hit the icy streets to enlist his neighbors in one more push for a region-wide system of "meaningful integration." 98 But Hartrich and the SSC found themselves in precisely the bind that Coleman had diagnosed. In the heart of South Shore, at the north end of the region, where black families were numerous and several elementary schools had already "tipped," the SSC claimed to find abundant support for the pilot. In fact, as SSC leadership explained, they wanted even more busing than Redmond was proposing, insisting that the Board approve a region-wide, two-way transportation program for fourteen schools, rather than a "token" one-way plan. ${ }^{99}$

The further south, east, and distant from black residency one traveled, however, the fewer white volunteers could be found. In South Chicago and Calumet Heights, white parents wrote to Redmond to make clear that they wanted no part of the SSC's plan. ${ }^{100}$ Meanwhile, some black South Shoreites had grown exhausted with the endless anxiety about racial stabilization. ${ }^{101}$ The kind of integration the SSC proposed relied on a political will that was in short supply and on a demographic formula that many saw as a tool for well-positioned whites to limit their exposure to their black neighbors, while shunting the burden to whites in adjacent neighborhoods. As a failed SSC lawsuit the previous year had demonstrated, quotas may have seemed reasonable on paper, but any attempt to place caps on transitioning populations in existing schools displaced black students in favor of white ones, spurring constitutional questions and undermining support for integration. ${ }^{102}$

It was this South Shore problem-resentment from black parents in the neighborhood and resistance from whites just outside of it - that

${ }^{97}$ Raymond R. Coffey, "Negroes, Yes, but How Many? Bryn Mawr: Integration in Balance," Scope, Chicago Daily News, Feb. 20, 1965, 11.

${ }^{98}$ Press Releases, Jan. 5-6, 1968, box 2, folder 3, SSC Records.

${ }^{99}$ Memorandum for Redmond et al., Dec. 6, 1967, box 2, folder 3, SSC Records.

${ }^{100} \mathrm{~S}$. Emmerman to James Redmond, Dec. 1967, box 2, folder 3, SSC Records.

101 "FOCUS demands," Chicago Daily Defender, Aug. 3, 1968, 10; "South Shore Group Against 1-Way Busing," Chicago Defender, Feb. 7, 1968; Steffes, "Managing School Integration," 16; and Danns, Desegregating Chicago's Schools, 36.

${ }^{102}$ Sklansky v. Board of Education of the City of Chicago, Civ. No. 66 ch6903 (1966) case file, Archives of the Clerk of the Circuit Court of Cook County. 
highlighted the necessity of starting anew, with racial quotas built into the brick, mortar, and ethos of a new schoolhouse. The magnet school, while avoiding mandatory transfer and retreating from plans for region-wide stabilization, promised to build integrated education from the ground up. On the same day that a thousand white demonstrators thronged Board offices to protest Redmond's limited busing plans, the Board of Education quietly approved the consulting contract for the city's first magnet school project. ${ }^{103}$ With a seat at the table, the SSC developed a working proposal for a "mini-magnet" school to be split across two facilities - one at Robert Black Elementary in South Shore and another in a synagogue twenty blocks south. Children from nineteen schools could apply for the 150 places in the inaugural cohort of first through sixth graders, with slots reserved for 50 percent white and 50 percent black enrollment. ${ }^{104}$ Light on specifics, the proposal mentioned class sizes of twenty-five pupils, "outstanding art," "modern mathematics," and "multi-ethnic textbooks." 105 In July of 1968 , the Board approved the proposal, appointed a principal, and began interviewing a multiracial pool of interested teachers. ${ }^{106}$ In September, students starting their classes at neighborhood schools across the South Side received forms to apply to Robert Black. The magnet was strong, pulling over sixteen hundred applications, prompting the Board to expand its first group to three hundred. ${ }^{107}$ The integrated faculty conducted a hasty self-guided in-service in the weeks before classes began. ${ }^{108}$ On September, 30, 1968, Chicago's first magnet school students stepped off their buses and walked into Robert Black Elementary. ${ }^{109}$

103 "1st Pupil Busing Hearing Set," Chicago Tribune, Jan. 25, 1968, 6.

104 "News of the Chicago Public Schools," Sept. 25, 1968, school files, box A-D, Robert Black folder, Archives of the Board of Education, City of Chicago (hereafter cited as CBOE Archives).

105 "Chicago Voter, Summer 1969," Schools—Black School folder, clippings file, Chicago History Museum Research Center (hereafter cited as Black School Folder). ${ }^{106}$ Proceedings of the Board of Education of the City of Chicago, July 10, 1968, 568-69, CBOE Archives (hereafter cited as BOE Proceedings).

107 "News of the Chicago Public Schools," (Publication not identified), Sept. 25, 1968; and "Sees 'Mini-Schools' as Solution," Southeast Economist, Sept. 19, 1968 (Black School Folder).

108 "News of the Chicago Public Schools," 3, no. 1, Nov. 1968, school files, Magnet Schools box, folder 1, CBOE Archives.

109 "Magnet School to Open Today," Chicago Tribune, Sept. 30, 1968, A10. When marking the nation's first magnet school, scholars cite McCarver Elementary School in Tacoma, WA, in 1968. The title may at least have to be shared. Christine H. Rossell, "Magnet Schools: No Longer Famous, but Still Intact," Education Next 5, no. 2 (Spring 2005), 44-49. 
While South Shore's magnet program was a consolation prize for the dashed dreams of regional stabilization, an opportunity on the North Lakefront, far from the live issues of racial transition, offered a chance for a magnet school in the ideal mold, "especially attractive, physically and academically," to be built from scratch. ${ }^{10}$ Redmond marketed his proposal for an eleven-acre parcel of federal surplus land with a public push in September of 1967, declaring that no site had ever held so much "potential ... for the future of the city." 111 By December, the Board of Education had been awarded the site at the boundary of the Uptown and Lakeview communities, and an act of educational urban renewal began. ${ }^{112}$

The Board opened the new year by hiring an A-list team of educational consultants, the city's premier architecture firm, and the dean of Northwestern University's School of Education. With a focus on "arts of communication," including theater, photography, and television, in November 1968 the North Side experiment was named Walt Disney Magnet School, and veteran educator Lorraine LaVigne was appointed its first principal. ${ }^{113}$ As a member of the Disney team with a courtesy faculty appointment at Northwestern, LaVigne felt her professional horizons broaden beyond the humdrum of the traditional principalship. ${ }^{114}$ To secure a school-community partnership, LaVigne recruited a council of "community personnel" from local civic organizations. Over the next two years, the ad hoc group became the Disney Magnet Advisory Council, a thirty-person body with an elected membership split among community members, parents, and staff. ${ }^{115}$ From the start, Disney had more administrative autonomy, more expert guidance, and more community participation than any school in the system.

${ }^{110}$ Redmond, Increasing Desegregation, B-26.

${ }^{111}$ Casey Banas, "'Magnet School' Plan Told: U.S. Hospital Site Sought by Redmond," Chicago Tribune, Sep 20, 1967, 2.

${ }^{112}$ Casey Banas, "U.S. Gives Schools 11 Acres," Chicago Tribune, Dec. 22, $1967,14$.

${ }^{113}$ Engelhardt, Engelhardt, and Leggett, Educational Consultants, "Final Educational Specifications, Walt Disney Magnet School, Marine Drive Campus, Chicago, Illinois" (draft 5, March 1969), Chicago History Museum Research Center, 2 (hereafter cited as Final Specifications); "1st Pupil Busing Hearing Set," Chicago Tribune, Jan. 25, 1968, 6; BOE Proceedings, report 68-756; and BOE Proceedings, report 68-849-1.

${ }^{114}$ Lorraine LaVigne, interview with the author, Nov. 4, 2015.

115 "Final Specifications," acknowledgements; LaVigne, interview; Sandra Simonson to Richard Reynolds, Aug. 3, 1970, box 22, folder 12, Uptown Chicago Commission Records, Chicago History Museum Research Center (hereafter cited as Uptown Chicago Commission Records); and Dieter Schulte, interview with the author, Nov. 3, 2015. 
Meanwhile, educational consultant Stanton Leggett drove the team toward his vision of the magnet school as "an educational catalyst for the city as a whole." ${ }^{116}$ Leggett subscribed to a philosophy of Individually Guided Education (IGE) and "open classrooms." IGE, developed in the mid-1960s at the University of Wisconsin, reimagined schoolteachers as flexible, cooperative teams of enterprising researchers. On a continuous cycle of assessment, instruction, and evaluation, IGE teachers tested and sorted pupils into ability-based groups. In place of traditional grade levels tied to age, students advanced on an individualized, "nongraded" progress-oriented scale. ${ }^{17}$ The open-classrooms model sought, quite literally, to tear down walls, clearing space for bright, carpeted expanses dotted with learning pods and modular furniture. ${ }^{118}$ While the "eggcrate" rigidity of industrial-era "ceramic vault" schoolhouses was the classic foil, the open classroom also posed dynamically across from the drab constrictions of suburbia, and as a humane refuge from the chaos of the ghetto. ${ }^{119}$ Together, these perspectives joined Deweyite revivals of child-centered antiauthoritarianism to a managerial futurism that disrupted the "subdued and static" practices of the traditional school. ${ }^{120}$ Instead of the "order and standardization" that thwarted creativity in the traditional school, Disney's play-based curriculum of "fun and excitement" promoted emotional self-discovery. ${ }^{121}$

In Chicago, the open classroom was meant to feed and feed off of the open city. Architect Bill Brubaker, president of Perkins and Will, became the virtuoso promoter of Leggett's spatial vision. In the same spirit that Havighurst had denigrated Willis's "four walls school," Brubaker and Leggett sought to break with the image of the schoolhouse as "an island with a chain link fence around it."122 Brubaker's sketches, which became conference room wallpaper during energetic

116“Final Specifications," ii.

${ }^{117}$ Herbert J. Klausmeier, James E. Walker, and Richard G. Morrow, Individually Guided Education in the Multiunit Elementary School: Guidelines for Implementation (Madison: Wisconsin Research and Development Center for Cognitive Learning, 1968).

${ }^{118}$ Leonard Buder, "Education: Breaking Down Formality for Fuller Expression of the Individual," New York Times, July 27, 1969, E9.

${ }^{119}$ Alexander Frazier, Open Schools for Children (Washington, DC: Association for Supervision and Curriculum Development, 1972), 75; and Harold Gores, as quoted in Commission on Civil Rights, Racial Isolation in the Public Schools (Washington, DC: Government Printing Office, 1967), 178.

${ }^{120}$ Klausmeier et al., Individually Guided Education, 25.

121 "Final Specifications," 11-12.

122 "Planning Seminar," July 1967 [sketchbook], box 1, folder 1, C. William Brubaker Papers, Ryerson Library, Art Institute of Chicago. 
pitches, bubbled with social visions of magnets as nodes of civic community, connecting a revitalized landscape of public works and transportation corridors. ${ }^{123}$ As Redmond affirmed of Brubaker's drawings, "they express tomorrow."124

As Principal LaVigne took on a schedule of interviews and speeches to ensure a smooth public reception and a diverse pool of applicants, the Board approved a summer pilot program, a few months behind Robert Black Elementary, but well ahead of the groundbreaking for Brubaker's new complex. ${ }^{125}$ By July, a group of sixty preschoolers, selected to reflect racial ratios in a broad stretch of the North Side, were attending a summer session in makeshift classrooms inside the defunct hospital on the Disney site. ${ }^{126}$ Over the following school year, the program doubled its enrollment, and Brubaker's glass-andsteel construction began to rise along the lake. ${ }^{127}$ With high stakes in Disney's success, the Board granted LaVigne significant autonomy in selecting teachers-and in dismissing those without "personal qualities that would predispose them to experimentation." 128 Psychological surveys helped match a "Profile of a Magnet School Teacher" to an interracial pool of applicants ready to defy the city's pervasive racial pessimism and embrace the school's curricular and architectural quirks. ${ }^{129}$ Working at Disney implied a tradeoff; the opportunity to pursue an innovative curriculum might mean dispensing with certain protections. As LaVigne remarked of her staff, "They don't pull out their union cards when a chair has to be moved."130

In addition to curricular and administrative innovations, and marked by its North Side setting, the technical content of integration also shifted at Disney. While South Side quotas stuck to a black-white binary, other nonwhite classifications proved relevant along the North

${ }^{123}$ Blair Kamin, "C. William Brubaker, 75" Chicago Tribune, May 29, 2002, 2C; and "Final Specifications."

${ }^{124}$ Christopher Chandler, "Plan 'Magnet School' for Lakefront on North Side," Chicago Sun-Times, Sept. 20, 1967, 59.

${ }^{125}$ Walt Disney Magnet School, box 22, folder 12, Uptown Chicago Commission Records,CHM.

126“Information Concerning the Disney Magnet School," box 22, folder 12, Uptown Chicago Commission Records.

${ }^{127}$ Joseph Zilguch, “The Effect of Elementary School Environment: Magnet versus Traditional" (PhD diss., Northwestern University, 1977), 24.

128 "Proposal for Recruitment of Teachers for Walt Disney Magnet School," Jan. 12, 1972, General Files, School of Education, T-C Cooperating Schools, Northwestern University Archives, Northwestern University.

129 "Cross-Section at Magnet May Be Impossible Unless," North Town News, Jan. 15, 1969, box 22, folder 12 .

${ }^{130}$ Joy Darrow, "Do Quotas Work? At Disney They Do," Chicago Defender, June 9, 1975, 11. 
Lakefront, where a diverse set of mid-century migrants from Appalachia, Puerto Rico, Mexico, and American Indian reservations had settled in among an older stock of Germans, Scandinavians, and Nisei Japanese. Social class was similarly varied, with working-class white homeowners inland, an expanding band of poorer migrants in the middle, and young singles and affluent old-timers along the lake. ${ }^{131}$ Unlike the South Side, however, there was no advancing color line. While "Spanish-language" populations surged into substantial minorities across Lincoln Park, Lakeview, and Uptown, black enclaves remained small and scattered. ${ }^{132}$

In 1970, the Disney Advisory Council recommended its balance formula, transmitting the newest US Census classifications onto recent patterns of local migration. Disney's student body was apportioned among five groups - white, black, Latin, American Indian, and Oriental - reflecting their share of the North and West Sides' school-age population. ${ }^{133}$ To draw black pupils, the Board dragged Disney's attendance boundaries south to Roosevelt Road, allowing LaVigne to recruit from the West Side. The Board approved Disney's balance formulas, but with quotas on uncertain legal ground, avoided the "q-word" entirely. ${ }^{134}$ LaVigne and the Disney Advisory Council also experimented with class-conscious definitions of desegregation. From the start, Leggett and LaVigne instructed teachers to create learning groups that contained a "complete spectrum" of socioeconomic status. ${ }^{135}$ New census data allowed Disney to translate these priorities into the school's enrollment procedures. Within each ethnoracial group, students were slotted for acceptance based on a five-category scale of occupational and educational backgrounds, determined by information solicited from parents. ${ }^{136}$

On the North Side at least, desegregation had become "diversity." ${ }^{137}$ Unlike most schoolhouses across the city, which Chicagoans

${ }^{131}$ Elizabeth Warren, Chicago's Uptown: Public Policy, Neighborhood Decay, and Citizen Action in an Urban Community (Chicago: Loyola University Center for Urban Policy, 1979); and Nancy Giesecke, "Diversity Makes Lake View 'Sociologist's Dream,", Chicago Tribune, Nov. 7, 1968, N3.

${ }^{132}$ Chicago Fact Book Consortium, Local Community Fact Book Chicago Metropolitan Area, Based on the 1970 and 1980 Censuses (Chicago: Chicago Review Press, 1984), 14-17.

${ }^{133}$ Zilguch, "The Effect of Elementary School Environment," 18.

${ }^{134}$ Citizens Schools Committee Report (Jan. 1970), box 52, folder 17, LPCA Records.

135 "Disney School Operation to Be Explained Tuesday," Chicago Tribune, Jan. 5, 1969, N5.

136“Walt Disney Magnet School Enrollment Policy," March 28, 1973, Magnet Schools box, folder 1, school files, CBOE Archives; and LaVigne, interview.

${ }^{137}$ For broader contexts, see John David Skrentny, The Minority Rights Revolution (Cambridge, MA: Harvard University Press, 2004); and Mark Brilliant, The Color of 
could tag with an urban shorthand of ethnic ownership, Brubaker's new complex, opened in 1973, was a space where no one group prevailed, where all were celebrated, and where intercultural contact was encouraged as an antidote to prejudice. Disney condensed an ascendant postcivil rights ideology of multiculturalism, where salad bowls, mosaics, and tapestries of cultural color replaced melting-pot metaphors of ethnic disappearance. In the Communication Arts Center (CAC), a special high-tech assembly hall, selected students from other Chicago schools attended Disney on a rotating schedule of two-week "residencies," culminating in the staging of elaborate multimedia productions. In the CAC residencies, Disney students were deputized as ambassadors of Chicago's multicultural hopes, inviting their peers to enjoy, however briefly, what it might feel like to live in an integrated city. Faculty had their own rituals by which they enacted their commitments to diversity. At staff barbeques before the start of every school year, teachers "balanced out" their class rosters, swapping student names until teachers in each pod had achieved a racial balance among their assigned students. ${ }^{138}$ Disney's improvised embrace of diversity exerted a strong moral force for those whose fates were tied to the school, solidifying the magnet concept's relationship to multicultural education.

Chicago's first magnet elementary schools had proven that integrated urban education could work, and that parents would line their kids up to be part of it. As plans for the city's first magnet high schools moved forward in the early 1970s, it became clear that Chicagoans had developed competing visions of what a magnet could be and who it was meant for. In 1970, the Board approved a proposal for Metro High, an experimental magnet "high school without walls," or more accurately, a high school without a building. ${ }^{139}$ High-profile business and cultural institutions agreed to provide space, equipment, and co-teachers for a roving enrollment of 350 students drawn from a citywide lottery. While Board of Education members had been persuaded by the involvement of corporate and civic elites, the Metro philosophy was decidedly antiestablishment. Metro students addressed their teachers and principal by their first names, designed their own classes, and even conducted hiring interviews for new staff. ${ }^{140}$ The city-as-classroom took

\footnotetext{
America Has Changed: How Racial Diversity Shaped Civil Rights Reform in California, 19411978 (New York: Oxford University Press, 2010).

${ }^{138}$ Larry Page, interview with the author, Dec. 16, 2015.

${ }^{139}$ Donald R. Moore, Thomas A. Wilson, and Richard Johnson, The Metro School: A Report on the Progress of Chicago's Experimental "School Without Walls" (Chicago: Urban Research Corporation, 1971), 97.

${ }^{140}$ Paula Baron, ed., Metro: The Chicago Public High School for Metropolitan Studies, 1980-1991 (self-pub., lulu.com, 2012).
} 
an expansive view of Chicago's educational resources. Advertising executives, architects, and telecommunications engineers stood on equal footing with yogis, ex-cons, folk dancers, improv comedians, and community activists. ${ }^{141}$

While experimentalism was pushed to new limits at Metro, a multimillion-dollar project planned for the Near West Side exposed the magnet concept's sharpest edges. Located at the border between the urban renewal abutting the University of Illinois Circle Campus and the burned-out blocks gutted in the 1968 riots, Whitney Young Magnet High School revived the regional-school dreams of an elite urban college preparatory school. As the school's top-flight facilities rose to swooning press coverage in 1974, its enrollment policy became a new forum for debate. To parents at nearby Crane High School-a high-poverty, all-black school where successive problems had provoked police intervention, a temporary shutdown, and an unfulfilled promise for renovation - the hype around Whitney Young was galling. ${ }^{142}$ The argument that a public amenity should first serve its local clientele had been central to the white defense of neighborhood schools. Now, black organizers like Earlean Lindsey leveraged localism, promising to march on Whitney Young's doorstep on the first day of school to enroll Crane's students. ${ }^{143}$ In a concession urged by sympathetic district administrators, the Board approved a set-aside of three hundred seats for Crane students in Whitney Young's first enrollment in $1975 .{ }^{144}$

While one battle for neighborhood representation had been won, others on the Near West Side, in the Jackson Boulevard neighborhood, engaged in a longer war for their community. Just down the street from Whitney Young, a cadre of self-declared "urban pioneers" had undertaken a heavy program to preserve a row of Victorian two-flats. Rehabbers in the Jackson Boulevard Association expected the new school's magnetism to boost their push for tasteful redevelopment. As enterprising professionals like Phil Krone and Bill Lavicka insisted at community forums, Whitney Young could only fulfill its hopes of attracting middle-class families if it abandoned inclusiveness toward the poor and underprepared. ${ }^{145}$ Editorial staff at the Chicago Tribune

${ }^{141}$ Moore, Wilson, and Johnson, The Metro School, 13-35.

${ }^{142}$ Dorthea Drew, "Academic and Racial Make-Up Challenged," Chicago Metro News, April 12, 1975, 1.

${ }^{143}$ Connie Lauerman, "Elitist Tag Hung on New School," Chicago Tribune, April 9, 1975, B3; and "Fight Plans for Young School," Chicago Defender, April 9, 1975, 3.

${ }^{144}$ Casey Banas, "Group Draws Up Race Quotas for Magnet School," Chicago Tribune, April 30, 1975, 3.

145 "Fight Plans for Young School"; and Andy Shaw, "Young School Admission Battle Tuesday," Chicago Sun-Times, April 7, 1975, 3, 20. 
agreed, declaring that "one frankly elitist school in the public system would not be too many." ${ }^{146}$ In 1977, the Board phased out Whitney Young's neighborhood component and, in 1979, introduced a competitive entrance exam. ${ }^{147}$ Quotas kept racial enrollments at even levels, and Whitney Young always kept black administrators at its helm, but the experiment with local mixed-income inclusion was over. The school had earned its stripes, both as an academic flagship and as a force for urban regeneration. Over five thousand applicants competed for five hundred places in the freshman class. ${ }^{148}$ Prominent Chicagoans, including new school superintendent Joseph Hannon and Operation PUSH (People United to Serve Humanity) chair Jesse Jackson enrolled their daughters at the school. ${ }^{149}$ Chronicling the replacement of vacant lots and derelict warehouses with upscale townhouses and new apartments, the local press ran with the story of a Near West Side renaissance, while education researchers declared Whitney Young the "nucleus for further residential development."150 Freed of attendance boundaries, urban magnet schools were meant to sever the link between providing public resources and the racialized market in private property. But as the Near West Side story illustrated, magnets' other function - as a spur to consumer confidence in the project of middle-class urbanism - had never shaken loose its spatial roots.

\section{Conclusion}

On the twenty-fifth anniversary of the Brown decision, Havighurst announced that segregation was now principally a northern, urban problem. Citing city-to-suburb migration statistics and sociologist William Julius Wilson's recent work on the urban underclass, Havighurst grasped for strands of hope. Metropolitan busing schemes were ideal, but politically inconceivable and legally moot. Youth employment programs might lift some at the bottom, but left racial isolation unaddressed. As he had done in 1964, Havighurst pinned his hopes on "renewal," endorsing the idea that multiracial, mixed-income magnet schools should follow in the wake of privatized redevelopment

\footnotetext{
146“Magnet Schools Need Magnetism," Chicago Tribune, March 31, 1975, A2.

147 “Access to Excellence," special supplement, Chicago Sun-Times, June 6, 1978, 4.

${ }^{148}$ Connie Moore and Daniel U. Levine, "Whitney Young Magnet High School of Chicago and Urban Renewal," Planning and Changing 7, no. 4 (Winter 1977), 152.

${ }^{149}$ Casey Banas, "Hannon Moves Up, but Seat's Still Hot," Chicago Tribune, July 24, 1975, 11; and Melanie Wojtelewicz, interview with the author, Nov. 29, 2015.

${ }^{150}$ Moore and Levine, "Whitney Young Magnet High School," 149; and Elizabeth Brenner, "Near West Side Undergoes a Construction Renaissance," Chicago Tribune, Dec. 29, 1977, n1.
} 
efforts in the urban core. ${ }^{151}$ By the end of the seventies, the "central city," where developers were placing their bets, had eclipsed the greater Southeast as the ideal ground for mixed-income multiculturalism.

In Chicago, the prolonged absence of any program of mandatory transfer had made school integration a matter of "choice." By the time authorities intervened-via a state desegregation plan in 1977 and a federal civil rights suit in 1979-magnets were the only policy with a supportive constituency and a ready pot of federal funds. With black Chicagoans hardly unanimous in their inclinations toward integration, white Southwest Siders continuing their tradition of resistance, and new Latino organizations echoing their opposition to acarreo forzada ("forced busing"), magnet schools sidestepped ethnic politics. The plans that followed-Access to Excellence in 1977 and Options for Knowledge in 1982-avoided mandated transfer and expanded the menu of non-neighborhood school choices. Superintendent Love's letter to parents in 1982 expressed an irony: embracing options had become the only option.

While no one disputed that magnets were integrated, the fact was that there were too few. With parental choice channeled into a contest characterized by extreme scarcity, magnets carried the expectation of an elite experience and shifted the criteria for success in urban education. When boosters cited magnet schools' popularity, manifested by the thousands of kids whose names sat on waiting lists for admission, they implied that both civil rights remedies and school curricula could be judged based on how well they functioned in a consumer market. ${ }^{152}$ Offering one of the stronger critiques of the emerging educational marketplace, the Chicago Urban League declared that choice-driven programs-whether bilingual centers in Pilsen, classical schools in Chatham, or entrance exams at Whitney Young-had a shared mission: to keep the black and poor far away from those who were not black and poor. That Urban League researchers could charge that Chicago was running, as they put it, an "anti-Black school system," when the count of black principals and the clout of black administrators was on the rise, suggested that systemic features of the city's political culture and political economy were more consequential in anchoring Chicago's educational inequities than devices like magnets could be counted on to transform. ${ }^{153}$

151 "Central City Renewal and Education," box 21, folder 16, Havighurst Papers.

${ }^{152}$ Joy Darrow, "A Very Good Example of the Busing Principle," Chicago Defender, Dec 8, 1975, 13.

${ }^{153}$ James W. Compton, Bernard Lacour, and Judson Hixson, “The Purposes and Goals of School Desegregation in Chicago," box 27, CUL folder, Latino Institute Papers, DePaul University. 
The invention of magnet schools in Chicago was not an elitist conspiracy. The combination of racial balance and specialized education as common goals among civil rights activists and liberal reformers was an earnestly adopted solution to the visible social problems of segregation, inequality, and urban decline. In a moment when the automation and suburbanization of industrial jobs remade the regional landscape, an interracial ideal of a community based in education began to be built atop an older racial order marked by residential property. But when undertaken under voluntary means, the redistributive potential of integrated education was buried under the logic of choice. While school designers tended to see the curricular and human relations aspects of their projects as magnets' most revolutionary contributions, the reform's real power lay in the same insight that Zuber and Havighurst had used to attack the neighborhood school - that attendance and enrollment policies were at the root of educational inequality.

The remarkable success of the choice-and-accountability movements of the late twentieth century is impossible to comprehend without the administrative prehistory of magnets. In Chicago, desegregation allowed administrators, parents, and activists to imagine what a future without the neighborhood school might look like and opened an infant marketplace of school options in a previously closed system. Linking these urban histories of school desegregation to intellectual histories of the choice-and-accountability movement that followed is a project in need of continued exploration. Contrary to some contemporary accounts, school reformers in the 1980s did not learn to embrace choice by rediscovering a 1955 essay by economist Milton Friedman. ${ }^{154}$ Without the engineered success of urban magnets, Reagan-era advocates would not have found such fertile ground for their radical pronouncements about the "panacea" of markets, and Clinton-era reformers would have been unable to push vouchers and charter schools with unchecked energy. ${ }^{155}$ Long before these projects were afoot, urban administrators and urban parents learned the lessons of choice in the context of voluntary integration. In a postindustrial city with persistent lines of racial segregation, such lessons were as much ideological as technical. As integrated escapes by which the middle class and the deserving poor could seek rescue from the schools that no one chose, magnets appeared to square the tensions between liberal multiculturalism and competitive meritocracy, all while enacting new inequalitiesand hiding those that had never gone away.

${ }^{154}$ Caroline Hoxby, ed. The Economics of School Choice (Chicago: University of Chicago Press, 2003), 1-2.

${ }^{155}$ John E. Chubb and Terry M. Moe, "America's Public Schools: Choice Is a Panacea," Brookings Review 8, no. 3 (Summer 1990), 7. 